\title{
ANALYSIS OF CHARACTER EDUCATION VALUES IN THE ENGLISH TEXTBOOK FOR THE TWELFTH GRADE SENIOR HIGH SCHOOL STUDENTS: BAHASA INGGRIS $S M A / S M K$
}

\author{
Elva Ayu Wardani, Zakiyah Tasnim, dan Wiwiek Eko B. \\ Jember University \\ Email: elvaayu09@yahoo.com
}

\begin{abstract}
This study examined what character education values presented in the English textbook published by the Ministry of Education and Culture of Republic Indonesia for grade 12. This type of this research is a content analysis. The data source of this research is the English textbook for grade 12 $S M A / S M K$. Fourteen speaking scripts of this textbook were analysed by using content analysis to find what values inserted in it. The finding showed that there were 17 character education values presented in the English textbook entitled Bahasa Inggris SMA/SMK. It means this textbook is suitable as the materials and guidance for English teachers to teach English and to develop the character education values suggested by the 2013 Curriculum to the students.
\end{abstract}

Keywords: character education values, content analysis, the english texbook, the 2013 curriculum

\section{ANALISIS NILAI-NILAI PENDIDIKAN KARAKTER DALAM BUKU TEKS BAHASA INGGRIS UNTUK SISWA KELAS DUA BELAS SMA: BAHASA INGGRIS SMA/SMK}

Abstrak: Penelitian ini menguji nilai-nilai pendidikan karakter apa yang disajikan dalam buku teks bahasa Inggris yang diterbitkan oleh Kementerian Pendidikan dan Kebudayaan Republik Indonesia untuk kelas 12. Jenis penelitian ini adalah penelitian analisis isi. Sumber data penelitian ini yaitu buku teks bahasa Inggris untuk SMA/SMK kelas 12. Empat belas potongan pembicaraan dari buku teks ini dianalisis dengan menggunakan analisis konten untuk menemukan nilai-nilai apa yang ada di dalamnya. Temuan penelitian menunjukkan bahwa ada 17 nilai pendidikan karakter yang disajikan dalam buku teks bahasa Inggris berjudul Bahasa Inggris SMA/SMK. Ini berarti buku teks ini cocok sebagai bahan dan pedoman bagi guru Bahasa Inggris untuk mengajar Bahasa Inggris dan untuk mengembangkan nilai-nilai pendidikan karakter yang disarankan oleh Kurikulum 2013 kepada para siswa.

Kata Kunci: nilai pendidikan karakter, analisis konten, buku teks bahasa inggris, kurikulum 2013

\section{INTRODUCTION}

In teaching and learning process, a teacher does not only deliver knowledge but also deliver character education values to the students. Character education is a program which has become the main feature of the 2013 Curriculum which has been socialized by the government since 2010 and since then all schools are requiring to implement this program(Faiziyah \& Fachrurrazy, 2013). The government instruct teachers to include the character education as values in teaching learning process including the books use. Character education can also be integrated in learning materials; therefore, when the teacher teaches the materials to the students, it is not only the materials itself, but also the character education values. In education, a textbook has an important role. For students, a textbook is one of the sources of information to increase their knowledge. For teachers, the material presented in textbooks may be use as a consideration in teaching (Lysa, 2013). Speaking script is always a part of a textbook. In this section, students can find much information by reading the speaking script. This condition makes speaking script an effective 
material to develop character education values. Students will not only learn English, but they can also learn good character values to help stirring them to the right path through their adolescence. Fahmy, et al. (2015) states that character education is very important especially for students, because it can be used to develop the knowledge and the students' skill in formal education. For example if the students have the fond of reading value means they are fond to read books to develop their knowledge that can help them more clever.

However, the result of character education is still questionable. The recent phenomena shows people's behaviours such as indiscipline, corruption, and abuse of power which are happening instead of decreasing (Thresia, 2014). It means that character education in the textbook has not been maximally delivered. In teaching learning process, a textbook can help students' learning progress. By using textbooks, students can learn many things from the materials in the textbook. Moreover, those materials should be evaluted to know the quality of the textbook. Prismarani (2014) argue that most English textbooks do not contain many character education values even when they are presented with color, pictures and quality paper. It can be said that the implementation of character education especially provided in the textbook needs to be continually examined to check its appropriateness and availability.

A textbook has an important role in education. Sheldon (1987) states that a textbook can be referred to as a published material especially designed to help language learners improve their linguistic and communicative ability. Therefore, it is important to evaluate a textbook to know about the quality of the material itself. According to Hutchinson \& Waters (1987), cited in
Sheldon (1988), textbook evaluation is basically a straightforward, analytical matching processes: matching needs to available solution. It means that textbook evaluation is a process of choosing what textbook to use in a particular course considering the need and the value of teaching. It reveals the strengths and weaknesses of certain textbooks for future adaptations by textbook writers, teachers and administrators (Litz, 2005). Ellis (1997) asserts that textbook evaluation helps teachers to make appropriate judgement and effectiveness of material which they use in their instruction. Sheldon (1988) adds that evaluation of textbook is useful for teacher to have knowledge about the material. Therefore, after evaluating a textbook the teacher will know the strengths and the weaknesses of the material in the textbook being used. In Indonesian context, moral degradation has become a greater concern of the society recently, such as drug abuse, sexual harrasment, and other psychological and behavioral disorders. Education plays an important role in addressing the issue with the integration of character building. Since the issue of character education attracts many parties, it becomes very important to know the content of the textbook concerning the character education values presented in the textbook. Therefore, character education values need to be reviewed in the following section.

Character education has been implemented in Indonesian schools since the 2013 Curriculum applied. Previously, character education was considered as the responsibility of religion, guidance and counseling teachers. However, following the 2013 Curriculum, all teachers are required to integrate character education into their teaching-learning processes (Hadi, 2015). Ulusoy \& Dilmaç (2012) say that character education is a process of transferring and 
acquiring values to children. Acat \& Aslan (2011) state that the purpose of character education is raising children as insightful, caring, optimistic, pious people and individuals who use their best capacity to do their best, and who understand the purpose of life. It also helps children to get to know and desire for the good and engaged in good actions eventually (Karatay, 2011). The importance of good characters for students is to provide them with necessary skills in order to overcome multiple challenges and issues within their social environment. By having good characters, they are expected to be able to implement and to improve their moral values and the abilities in their daily life (Nurhasanah \& Nida, 2016). Hadi (2015) says that having a good character needs a continuos process of learning implemented in education. Good characters will not be developed properly if they are not nurtured through education. Therefore, character education is expected to support the establishment of Indonesian new generation (Faiziyah and Fachrurrazy, 2013).

Curriculum is needed in conducting education because it is the heart of education (Suparman, 2005). Curriculum has an important role in education to evaluate materials and also a guideline for all the teachers to conduct teaching and learning process. Based on the government decree number 20 (2003), curriculum is a set of planning and setting of the objectives, content, and the material of teaching learning process used as the guideline of teaching to achieve the educational goal (Darrin, 2014). The current curriculum used in Indonesia for elementary and secondary school levels is called the 2013 Curriculum. It covers two main components: core competencies and basic competencies. Then it is developed into syllabus containing core competencies, standard competencies, indicators and main materials. Syllabus is then developed into lesson plans. This curriculum emphasizes to teach the students not only cognitive domain but also psycomotor and affective domains which develop the character education values. Therefore, having good cognitive domain and good character values are thefocus of the 2013 Curriculum. There are eighteen character education values based on the 2013 Curriculum provided by The Ministry of Education and Culture of Republic Indonesia (2010) that should be implemented in the teaching and learning process. They are religious, honest, tolerant, disciplined, hardworking, creative, independent, democratic, curious, nationalistic, patriotic, appreciative, communicative, peace loving, fond of reading, environment aware, socially aware and responsible.

Harmer (2007) states that the most important aspect of textbook use is for teachers to try to engage students with the content they are going to be dealing with. Teachers and students use textbooks as resources that provide the main source of information, guidance and structure (AlGhazo \& Smadi, 2013). Lysa (2013) claims that textbooks can be used as a teaching materials to implement character education values to the students. It is expected that textbooks can influence the students' characters because of the information shown. In presenting the text, the author of the textbooks should think about a message that they want to convey to the students. This is a chance for the author to include the character education values in the teaching learning activities through the materials in the textbooks. Therefore, it is very ideal that a textbook contains character education values either explicitly or implicitly stated and it is a good way to build students' attitude through teaching and learning 
activity by using textbooks as the teaching materials contains character education values.

Some previous related studies on analysing textbook by focusing in reading materials were conducted. Soniawan (2012) conducted a research by analysing character education values in the English textbook especially on reading materials for the eleventh grade senior high school students. His research found that, among the 18 character education values, democratic is absence in the reading materials. Syahbana \& Prtama (2017) analysed a textbook; Kreatif (Kreasi Belajar Siswa Aktif) especially in reading materials for the tenth grade students published by Viva Pakarindo. His research found that the reading materials in the textbook do not contain religious, democratic, environment aware, creative and fond of reading values. Rohmah (2018) conducted a research by analysing character education values in the textbook entitled "Buku Bahasa Inggris SMA/SMK" especially in reading materials for the Tenth Grade students published by The Ministry of Education and Culture of Republic Indonesia. Her research found that the reading materials in the textbook do not include environment aware, independent, democratic and fond of reading.

Each research showed that the textbooks from different publishers that have beenevaluated are suitable for the students' needs covering the values of character education provided by the government, but there are not all 18 values covered in the textbook. It means that further research needs to be done. To fill the gap, this research analyzed the speaking script of an English textbook used for Senior High School learners to find out what character education values covered in it to support what the government has said that the implementation of character education should be applied continually. It is based on "Panduan Pelaksanaan Pendidikan Karakter" saying that character education should be implemented at schools explicitly, objectively, honestly, and continuously (Kementerian Pendidikan dan Kebudayaan, 2010).

\section{METHOD}

\section{Data of the Study}

This study was Conducted in Indonesian context where English is used as a foreign language instead of additional or second language. The object of this research was an English textbook which was expected to have the character education values because the book is provided by the Ministry of Education and Culture of Republic Indonesia for the implementation of the 2013 Curriculum. The textbook has 250 pages and sixteen chapters. The title of the English textbook is Bahasa Inggris SMA/ SMK published in 2015 by Pusat Kurikulum dan Perbukuan, Balitbang, Kemdikbud. This textbook is for the Twelfth Grade Senior High School Students written by Widiati, et al. (2015) and edited by Noorman, et al.

\section{Data Analysis Technique}

The design of this research was content analysis because the purpose of this research was to analyse the character education values presented in the speaking script of an English textbook. The researcher described the content of the speaking script by referring to the character education values based on the 2013 Curriculum provided by the Ministry of Education and Culture of Republic Indonesia. The result of the analysis was presented in the form of description. This research applied content analysis (Ary, et al., 2010) to analyse the speaking script from the textbook compared with eighteen character education 
values based on the 2013 Curriculum provided by the Ministy of Education and Culture as the method to collect the data.

\section{Procedures of Analysis}

In this part, the researcher analyzed the collected data by using content analysis. It is a type of analyzing the material to know the phenomenon by studying certain documents. This type of analysis answers the meaning or the characteristic of the reflected material which consists of written or visual documents (Ary, 2010). This research analyzed the speaking script in the textbook in relation to character education values suggested by the Ministry of Education and Culture of Republic Indonesia. The procedures of analysing the data were based on Ary's steps (2010:458) as the following.

- Specifying the phenomenon to be investigated (the researcher analyzed the character education values).

- Selecting the media from which the observations are to be made (the media for the analysis was an English textbook: Bahasa Inggris SMA/SMK published by the Ministry of Education and Culture of Indonesia).

- Formulating exhaustive and mutually exclusive coding categories (the researcher used the instrument to analyze the English textbook. In this case, the researcher developed the instrument, based on the description of the 18 character education values provided by the government by making the indicators for each values).

- Deciding on the sampling plan to be used (the research focused on the speaking script from the English textbook).

- Analyzing the data by applying the instrument that has been established its validity and reliability. In this research, the establisment of the validity was done by asking the interaters to read and understand the research instrument. In addition, the establishment of reliability was done by asking the interaters to analyze one speaking script by applying the instrument provided.

- Explaining the instruments before the researcher asked the interaters to read and understand it. After they read the instrument, the interaters and the researcher discussed the instrument to make the interaters more understand. Then the researcher asked them to analyze one speaking script. After that, they were discussing about their analysis's result.

- Writing the summary of the interaters' result.

- Drawing the conclusion based on data analysis.

\section{RESULTS AND DISCUSSION Results}

This section contains the finding of the research. It is about the availability of character education values in the speaking script of an English textbook entitled Bahasa Inggris SMA/SMK based on the 2013 Curriculum suggested by the Ministry of Education and Culture. The Speaking script of chapter 1 has five dialogues. From dialogue 1 it can be found that there are four character education values covering socially aware, fond of reading, responsible and communicative. Here is the dialogue.

Anita: May I help you? (socially aware).

Fatah: Yes, please. I need a book entitled

"Visiting Seattle". (fond of reading)

Anita: Sure, we have one copy left. I'll get it for you. (responsible)

Fatah: Thanks (communicative)

Chapter 1. page 7

The authors present the socially aware value in the speaking script that 
discuss about a librarian who helps a visitor to find a book. The authors want to tell the students that they should help each other who needs a help. From the Anita's statement "May I help you?", Anita shows the action that tends to assist other people who need help. It means that Anita's statements contain socially aware value and also represent one of the indicators of socially aware value that is doing activities for helping others. The second value that was found is fond of reading it can be seen from Fatah's statement "I need a book entitled Visiting Seattle", Fatah statment presented one of the indicators of fond of reading value, that is, fond to vitir library and read the literature in there. The third value that was found by the researcher is responsible. The authors present the responsible value in the speaking script that discuss about a librarian who helps the visitor to find a book. The authors want to tell that as the students they have to do their duties and obligation. In the conversation Anita as the librarian does her duties to help the visitor to find a book. It can be seen on Anita's statement "I'll get it for you". It also represents one of the indicators of responsible value that is doing the duties and obligation. The last value that was found is communicative. It can be seen from Fatah statement "Thanks" it means that Fatah able to communicate with a good language to others.

From dialogue 2 it can be found that there are four character education values covering responsible, disciplined, honest and communicative. Here is the dialogue.

Made: We have to submit the report of our
visit to Lake Toba (responsible) tomorrow
(discipline) but I think there are still lots of
problems with the grammar, spelling, and so
on. (honest)
Hilda: What if I take half of it and I'll edit the
rest after I finish this one. (communicative)
Made: That's very thoughtful of you. Thanks a lot. (communicative)

Dialogue 2, page 7

The authors present the resposible and diciplined values in the speaking script that discuss about two students doing their assignment from the teacher. The authors want to tell that as the students they have to follow the rules and regulations. In the conversation, Made and Hilda have to submit the report of their visit to Lake Toba tomorrow (in the next day). From the conversation it contains responsible and disciplined values because the speakers are responsible to submit their assignment from the teacher on time, which means they are also disciplined. Their action also represents one of the indicators of responsible and diciplined values, that is, finishing duties and obligation on time. From Made's statement "but, I think there are still lots of problems with the grammar, spelling, and so on" it can be conclude that it contains honest value, because Made are telling the truth that their assignments still have lots of problem. The authors present the communicative value in the speaking script that discuss about two students who cooperate in doing their assignment. The authors want to tell that we have to work together to do our duties. From the conversation it can be concluded that it contains communicative value, because the speakers cooperate in doing their assignment. From dialogue 3 it can be found that there are three character education values covering responsible, hardworking and communicative. Here is the dialogue.

Father: Exam is around the corner. It's about time to go back to your study.

Son: Okay Dad. (responsible)

Father: If you want to pass the exam, you have to study harder. (hardworking)

Son : Thanks, Dad. (communicative) Dialogue 3, page 10 
The authors present the responsible and hardworking values in the speaking script that discuss about a father who asks his son to study because exam is around the corner and he also suggests him to study hard if he wants to pass the exam. The authors want to tell that as the students they have to do their obligation to study and if they want something they have to work hard to get what they want. From the conversation it can be concluded that it contains responsible and hardworking values, because one of the speakers (Father) asked his son to study and also to suggest that if he wants to pass the exam, he must study harder. From the Son's statement "Thanks Dad" it can be conclude that it contains communicative value because the Son is communicating with a good language.

From dialogue 4 it can be found that there are three character education values covering democratic, creative and environment aware. Here is the dialogue.

Mr. Lukman : If you want to be a chair of OSIS, offer a good program to improve school environment (creative, environment aware) Nyoman : Sure, I will. (democratic)

Dialogue 4, page 10

The authors present the creative value in the speaking script that discuss about a teacher who suggests his student to offer a good program to improve school environment if he wants to be a chair of OSIS. The authors want to tell that if they want to do something they have to think first to get a good result. One of the indicators of creative value is delivering suggestion or a new idea. From the conversation it can be concluded that it contains creative value because Mr. Lukman gives a suggestion or idea to Nyoman to offer a good program if he wants to become a chair of OSIS. The authors present the environment aware value in the speaking script that discuss about a teacher who suggests his student to offer a good program to improve school environment if he wants to be a chair of OSIS. The authors also want to tell that by offering a good program for the school environment it means that he will invite the other students and also the teacher to pay attention and keep the school environment clean. From the conversation it can be concluded that it contains environment aware value because Mr. Nyoman's idea is usefull for the school environment, and those ideas represent one of the indicators of environmentaware value that is the effort for keeping the environment clean. The conversation also contains democratic value, because they are discussing first about what the Nyoman should do before deciding something.

From dialogue 5 it can be found that there is one character education value, that is, socially aware. Here is the dialogue.

Joko: If I am elected president, I will waive taxes for poor people. (socially aware, patriotic)

Edwin: I wish you all the best. (communicative)

Dialogue 5, page 11

The authors present the socially aware value in the speaking script that discuss about two speakers who talk about helping poor people by waiving taxes. The authors want to tell that the students they have to help each other. From the conversation it can also be concluded that it contains socially aware value because Joko's statement represents one of the indicators of socially aware value that is doing activities for helping others.

The speaking script of chapter 3 has one dialogue. From this dialogue it can be found that there are nine character education values covering disciplined, respon- 
sible, creative, independent, curious, tolerant, fond of reading, democratic and communicative. Here is the dialogue.

Indah: Hey guys, I think we should finish our Biology assignment before Sunday. (responsible)

Bagus: You're right! It should be submitted on Monday. (discipline)

Lyla: But, do you have any idea what we should write about?

Lyla: We should make a poster about underwater life Bagus : Let's have a look at some references from the internet. Maybe we can get some ideas. (creative) (curious) (independent)

Lyla: That's a good idea! (tolerant)

Bagus: I reckon we have to think of an animal underwater and make a poster about it. Indah: Look at this one. It's a giant squid.

Lyla: Have a look at the size! It's very big!

Indah: Listen, the article says that the size can be 10 meters long. It's as big as a school bus! (fond of reading)

Lyla: Wow! I think a giant squid is very unique. Indah: I'd say we should make a poster about a giant squid.

Bagus: Yes, we can print out the picture and write the facts about a giant squid. I think it will be great! (creative)

Lyla: That's a good idea. Here, pay attention to this. The article says that a giant squid's eyes are the size of a diner plate. Very interesting! (fond of reading, tolerant)

Bagus: Really? Wow! Now, I really think we should make a poster about it.

Lyla: yeah, I think so (tolerant)

Indah: okay let's get started (democratic) (communicative)

Dialogue 1, page 30

The authors present the disciplined and responsible value in the speaking script that discuss about three students who talk about their assignment. The authors want to make the students have disciplined and responsible values by showing cases in the conversation that as students they have to do their obligation to responsible in doing the assignment from the teacher and submit it on time. The authors also want to make the readers have creative value. In the conversation, the speakers said about their assignment to make a poster about underwater life, and one of them says that before making a poster they should have a look at some references from the internet that could give them some ideas. That action shows one of the speakers represents creative value, because he is thinking a new way (looking at the references in the internet) before doing something (making a poster). Independent value also found in this dialogue.

The authors want to make the students have independent value by trying to do everything with their own ability. From the conversation it can be concluded that it contains independent value because the students are trying to finish their assignment without asking a help from the teacher. It also represents one of the indicators of independent value that is trying to do everything with their own abilities. The authors present the curious value in the speaking script that discuss about three students who discuss about their assignment. The authors want to tell that as students they have to find so much information from any resources to finish their work. One of the indicators of curious value is exploring the information in any resource. From the conversation it can be concluded that it contains curious value because the speakers try to find ideas/information from the internet to help them finish their assignment. From the conversation in can be concluded that it contains communicative value, because when they are dicussing about their assignments they use a good language.

The authors present the tolerant value in the speaking script that discuss about three students who discuss about their assignment. The authors want to tell that as the students they have to appreciate the idea or opinion from others. From the 
statements " that's a good idea and yeah I think so" they represent tolerant value because those statements refer to attitudes that respect opinions from others. The authors present fond of reading value in the speaking script that discuss about three students who discuss about their assignment by searching the information in articles from the internet. The authors want to make the students have fond of reading value by searching information to develop cognitive skill. From the statement: "listen the article says that the size can be 10 meters long" it can be understood that it contains fond of reading value because the speakers like to read the information to develop their knowledge; in this case they read the information that can help them in doing their assignment. The authors present democratic value in the speaking script that talks about three students who discuss about their assignment. The authors want to tell that as students if they want to decide something they have to discuss it first. One of the indicators of democratic value is discussing to finish something. In the conversation the speakers discuss about their assignment. After a long discussion they decide to make a poster about underwater life. From the conversation it can be understood that it contains democratic value because before they decide to do something they discuss it first to make a decision.

The speaking script of chapter 4 has four dialogues. From dialogue 1 it can be found that there is one character education value, that is, appreciative. Here is the dialogue.

Zahra: Have you heard the latest news about our school?

Raisa: No. What about it?

Zahra: It got A from the National Accreditation Body.
Raisa: Wow! That's terrific, we should be very proud. (appreciative)

Zahra: It means that our school is of good quality. (appreciative)

Dialogue 1 , page 45

The authors present appreciative value in the speaking script that discuss about their school achievement. The authors want to tell that as students they have to appreciate other's achievement/success. One of the indicators of appreciative value is giving appreciation to someone's success or achievement. From the statements "We should be very proud and it meand that our school is of good quality. It can be concluded that it contains appreciative value, because the speakers feel so proud of their school's achievement. It means they are appreciating the achievement of their school for getting A from the National Accreditation Body.

From dialogue 2 it can be found there is one character education value, that is, religious. Here is the dialogue.

Toni: Mum is planning to buy us each a study desk. Nina : We don't need to share then. Thank God. (religious)

Toni: Yes. I wanted a bigger study desk for a long time.

Dialogue 2, page 47

The authors present religious value in the speaking script that talks about a brother and sister who are happy, because they will get new desks from their mother. The authors want to tell that students have to say thanks and remember God if they are happy or sad. One of the indicators of religious value is always remember God when we are sad or happy; for example by stating "thank God or Alhamdulillah". From the conversation it can be concluded that it contains religious value because the speakers are happy for getting new desks and 
one of them says " Thank God" it means they remember God when they are happy.

From dialogue 3 it can be found there is three character education value, covering socially aware, honest, and communicative. Here is the dialogue.

Risna: Hello?

Fadil: Hi. This is Fadil.

Risna: Hi, Fadil. You sound terrible. Are you all right? (socially aware) Fadil: No I am not. I can't go to school today. (honest)

Risna: Oh, I am sorry to hear that. What's the problem? (socially aware)

Fadil: My stomach hurts terribly. I think I

have a fever as well. (honest)

Risna: Oh, no. You have to see the doctor soon.

(socially aware)

Fadil: This evening

Risna: Good. Get well soon, Fadil. Bye (socially aware)

Fadil: Thanks. Bye. (communicative)

Dialogue 3, page 49

From the conversation it can be concuded that it contains socially aware value, because Risna's statements show the attitudes and actions for caring and helping people in this case her friend, Fadil. It also contains honest value. It can be seen from Fadil's statement " No, I'am not. I can go to school today". It means that Fadil tell the truth that he can not go to school beacuse he is sick. Fadil also shows action that represents communicative value, because he is communicating with good language by saying thanks to Risna. From dialogue 4 it can be found that there are five character education values covering socially aware, disclipned and responsible honest and communicative. Here is the dialogue.

Luki: What's the matter with you? Are you feeling ok? (socially aware)

Farah: No, not really. I have a toothache. (honest)

Luki: Have you seen the dentist? (socially aware)
Farah: Not yet. Many things to do in the office. (responsible)

Luki: You must talk to the boss. You have to

leave early and go to the dentist. (socially aware)

Farah: I'll do that. (disciplined)

Luki: Hope you'll feel better. Take care. (socially aware)

Farah: Thanks. (communicative)

Dialogue 4, page 50

From the conversation it can be concluded that it contains socially aware value, because Luki's statements show the attitudes and actions for caring and helping people in this case his fiends Farah. In the conversation it also contains discipline and responsibe values because as the employee of the company, Farah is following the rules to do her duties and obligation first before seeing the dentist although she has a toothache. It also contains honest value becasue Farah is telling the truth that she is not feeling okay because she have tootache. It can be seen from Farah's statement "No, not really. I have a toothache". Farah also shows action that represents communicative value, because he is communicating with good language by saying thanks to Luki.

The speaking script of chapter 9 has one dialogue. From this dialogue it can be found that there are five character education values covering curious, appreciative, socially aware, patriotic and nationalistic. Here is the dialogue.

Benny: Hi, Ana. I heard you visited ceramic village in Bethek last week. Is it true? (curious)

Ana: Yes you're right!

Benny: Anything interesting? (curious)

Ana: It was the first time for me to visit the pottery manufacturing area. I was surprised that there were more than 10 ceramic factories in Bethek. You know Bethek is not a large area but...

Beny: Do they have any association? (curious) Ana: No, they are kind of traditional manu- 
factures. They have a good potentials actually. Their ptoducts show a high level of creativity. (appreciative)

Benny : I see.

Ana: I think the government need to help them improve their quality by setting up an association for the producers and the artists. (patriotic)

Beny: You're right. The association can also help them market their products to other places, not only in Malang area. (patriotic) Ana: You're right. They might even sell their products to overseas market. (nationalistic) Benny: Alright, let's think of how we can help them (socially aware)

Ikhsan: Atim, do you know how to make ceramic products? (curious)

Atim: Yes, first mix the materials.

Ikhsan: What are the materials? (curious)

Atim: Kaloin, felspard, kwarsa and ball clay. Mis them with water.

Ikhsan: What's next? (curious)

Atim: Filtering. The mixture must be flteres to get the smooth material

Ikhsan: I see, and then they form it? (curious)

Atim: Yes, corret. They do it by poring the mixture in a cast, let it stand until it dries.

Ikhsan: then... (curious)

Atim: the next step is firing in 1.220 degrees celcius, it takes 10 hours for firing and 24 hours for cooling down.

Ikhsan: Wow, that's a long process

Atim: The last step is decorating. Here, the artists draw different kinds of pictures depending or the customer's order their own creation.

Dialogue 1, page 138-139

From the conversation it can be concluded that it contains curious value because the speakers (Benny and Ikhsan) are asking and exploring the information from their friends (Ana and Atim) about ceramic village in Bethek and how to make the ceramic. It means they are curious with the topic they are discussing. In the conversation it also contains appreciative and socially aware values because the speakers acknowledge and respect what others do (the people who make ceramic in Bethek). It means the speaker is appreciating their products. It contains socially aware value, because the speakers are thinking about what they need to do to help Bethek people improve the quality of their products. It means they care and want to help them. From the conversation it also contains patriotic and nationalistic values, because the speakers are thinking about what they should do toke increase domestic products in this case the ceramic which made by Bethek people.

However the character education values that is not presented in the English textbook Bahasa inggris SMA/SMK is peace loving.

\section{Discussion}

In this section, the researcher discusses the highest values and the unavailable values as the highlight from the analysis which is linked to the government, English teacher, and textbook author's role as well as the similar previous study. Socially aware is the highest value found from the analysis which is implemented 11 times in 5 speaking scripts. Socially aware value refers to attitudes and actions that tend to assit other people who need help (Kemendiknas, 2010). In Syahbana's study (2017) socially aware iplemented in times in 4 reading materials. It can be seen that the government has an expectation for these values which can give the influence for the students to help each others. Thus, it is important for them to own this value and to get good attitudes. The students are expected to implement this value in their daily lives such as: helping poor people and care with the society.

On the other hand, the value that does not presented in the speaking script is peace loving. Peace loving value refers to attitudes, speech, and actions that cause other people to feel happy and secure due to one's presence (Kemendiknas, 2010). In fact there are many bullying and harassment cases at schools. Therefore, the au- 
thors should also insert this value in the English textbook, because it will influence the students for doing something that makes the community happy and peaceful. For example, the authors can provide speaking script that discuss about forgiving others' mistake and frienship. The finding showed the explanation about each value found by the researcher. From the explanation above. It can be concluded that the English textbook: Bahasa Inggris SMA/SMK for the Twelfth Grade Senior High School Students is appropriate as the teaching material to develop character education values to the students especially in the speaking scripts, because the result of analysis found there are 17 character of 18 character education values that should be included in the textbook based on the 2013 Curriculum. By implementing character education values, the students will be trained at least in learning English to be known and practiced as well as become the identity as characterized students.

\section{CONCLUSION}

Based on the result of the analysis in the English textbook entitled Bahasa Inggris $S M A / S M K$ for the twelfth grade senior high school students especially in speaking script by using content analysis, it can be reported that there are seventeen character education values presented in this textbook covering socially aware, responsible, discipline, communicative, hardworking, creative, environment aware, independent, curious, tolerant, fond of reading, honest, democratic, appreciative, religious, patriotic and nationalistic. Socially aware is the highest value found from the analysis which is implemented 11 times in 5 speaking scripts. In addtion, Communicative, environment aware, indiciplined, tolerant, fond of reading, honest, democratic and reli- gious are the least value found from the analysis which are implemented 1 times in the speaking scripts.

However, the character education value that does not found is peace loving. From the result, it can be concluded that this English textbook is appropiate as the teaching material to develop character education values to the students, because this textbook contains seventeen of eighteen character education values that should be included in the textbook suggested by the 2013 Curriculum. It is better than the regulation of the Ministry of Education and Culture who says that the English textbook for Senior High School should implemented at least eight values in the text.

\section{ACKNOWLEDGMENT}

With the completion of the research and writing of this article, we thank all those who have helped us both in research and in writing this article. In particular we would like to thank to the editorial board of the Jurnal Pendidikan Karakter for publishing our article.

\section{REFERENCES}

Acat, M.B. \& Aslan, M. (2011). Character education competence scale of schools. Journal of Values Education, 9 (21), 727.

Al-Ghazo, A. \& Smadi, O.M. (2013). A content analysis of the english reading text's aunthenticity in student's book of action pack eleven in Jordan. European Scientific Journal, 9(29), 342-359. Jordan. DOI: http://dx.doi.org/10.19044/esj.2013.v9n29p\%25p.

Ary, D. Jacobs L., Sorensen, C., Razafieh, A. (2010). Introduction to research in education eighth edition. Canada: Wadsworth Cengage Learning. 
Darrin, A. (2014). An Analysis of English Textbook for First Grade of Senior High School "Bahasa Inggris untuk SMA/MA dan SMK/MAK kelas X" Published by Putra Nugraha and Used in SMAN 18 Surabaya Based on Basic Competence of Curriculum 2013. Surabaya: Surabaya University.

Ellis, R. (1997). The empirical evaluation of language teaching materials. ELT Journal, 51(1): 36-42. Retrieved from: https://eclass.uoa.gr/modules/docu ment/file.php/ENL264/materials \%2 0evlauation.pdf.

Fahmy, R., Bachtiar, N., Rahim, R., Malik, M. (2015). Measuring student perceptions to personal character buildings in education: An Indonesian case in implementing new curriculum in high school. Procedia - Social and Behavioral Sciences, 211, 851-858. DOI:10.1016/j.sbspro.2015.11.112.

Faiziyah, N. \& Fachrurrazy. (2013). The implementation of character building in english subject at junior high school 3 Malang. Journal-online UM, 4(2), 1-21. Retrieved from: http://karyailmiah.Um.ac.id/index.php/sastrainggris/article/view/26275 [retrieved on 2 nd November 2018].

Hadi, R. (2015). The integration of character values in the teaching of economic: A case of selected high schools in Banjarmasin. International Education Studies, 8(7), 11-20. DOI:10.5539/ies.v8n$7 \mathrm{p} 11$.

Harmer, J. (2007). How to teach English. London and New York: Longman Inc.

Hutchinson, T. \& Waters, A. (1987). English for specific purposes: A learning centred approach. Cambridge: Cambridge University Press.

Karatay, H. (2011). Using literary works in character education. Turkish Studies International Periodical For The Languages, Literature and History of Turkish or Turkic 6(1), 1398-1412. DOI: 10.7827/TurkishStudies.2191.

Kementerian Pendidikan Nasional. (2010). Buku panduan pendidikan karakter SMP. Jakarta: Badan Penelitian dan Pengembangan Pusat Kurikulum.

Litz, D.R. (2005). Textbook evaluation and ELT management: A South Korean case study. Asian EFL journal, 48, 153. Retrieved from: https://www.asian-efl-journal.com/Litz_thesis.pdf.

Lysa, P. (2013). Character education values in reading section of e-english textbook for senior high school students grade XI. Semarang University: Journal of English Language Teaching https://journal. Unnes.ac.id/artikelsju/elt/1559 [retrieved on 2 nd November 2018].

Nurhasanah, N. \& Nida, Q. (2016). Character building of students by guidance and counseling teachers through guidance and counseling services. Jurnal Ilmiah Peuradeun, 4(1), 65-76. DOI: 10.13140/RG.2.1.3085.4160.

Prismarani, D.F., (2014). An analysis of listening materials based on the national character building for the seventh year students of junior high school. Thesis. Jember: Jember: Jember University. Retrieved from: http:/ / repository.unej.ac.id/handle/123456789/ 63170. 
Pusat Kurikulum dan Perbukuan. (2011). Pedoman pelaksanaan pendidiikan karakter (online). Jakarta: Badan Penelitian dan Pengembangan Kementerian Pendidikan Nasional.

Rohmah, H. (2018). Analysis of character educationvalues in the English textbook "Bahasa Inggris SMA/SMK". Jember: Jember University.

Sheldon, L.E. (1987). Introduction in ELT textbooks and materials: Problems in evaluating and development. Modern English publication in association with the British Council.

(1988). Evaluating ELT textbooks and materials. ELT Journal, 42, 237-246. DOI: 10.1093/elt/42.4.237.

Soniawan, F. (2012). Character education analysis of 2013 curriculum english textbook entitled: Bahasa Inggris for eleventh grades senior high school. Surabaya: Surabaya University: Students Journal Unesa, 4(2). Retrieved from: http:/ /jurnalmahasiswa.unesa.ac.id/index.php/retain/article/vie $\mathrm{w} / 16064 / 20058$.

Suparman, D. (2005). Konsep dasar pengembangan kurikulum. Jakarta: PAUPPAIUT Jakarta.
Syahbana, A. \& Pratama, M.R.A. (2017). The analysis of English reading texts based on national character and cultural education on course book for the tenth grade at the state of senior high school in Pamekasan. OKARA: Jurnal Bahasa dan Sastra, 11(1), 179-192. DOI: http:/ /dx.doi.org/10.19105/ojb s.v11i1.1243.

Thresia, F. (2014). Teaching english based on character education at senior high school Metro. The Second International Conference on Education and Language (2nd ICEL), 53-59. Retrieved from: http://artikel.ubl.ac.id/index.php/ic el/article/view/259/795.

Ulusoy, K. \& Dilmaç, B. (2012). Values education. Ankara: Pegem.

Undang-Undang Republik Indonesia Nomor 20 Tahun 2003 tentang Sistem Pendidikan Nasional.

Widiati, U., Rohmah, Z., \& Furaidah. (2015). Bahasa Inggris SMA/SMK Kelas XII. Jakarta. Pusat Kurikulum dan Perbukuan, Balitbang. Kemdikbud. 